\title{
How Is Career Development Model in Marketing Unit?
}

\author{
Susan Uswatun Hasana ${ }^{1}$, Abdul Rahman ${ }^{2}$, Nefi Aris Ambar Asmara ${ }^{3}$, Edah Jubaedah ${ }^{4}$ \\ Politeknik STIA LAN Bandung, Jl. Cimandiri 34-38 Bandung 40115 $5^{1234}$
}

\{susan.hasana@gmail.com\}

\begin{abstract}
The existence of human resources in the company has the same importance with the work itself. Because of human resources as a determining factor for a company, the competency of them to be an important aspect and a success key in achieving goals. This study focuses on PT Bank Negara Indonesia (Persero), Bandung College Branch Office. By using a qualitative method aimed to analyse career development and the obstacles faced in carrying out career development, the study results that there are several obstacles in improving the career of employees at the Marketing Department. On the other hand, the study highlights the existence of orderly and structured mechanism for employees so that employees can openly propose to carry out career development through promotion with predetermined requirements. As recommendation, it is needed a clear strategy related to mission and vision of company, so that the superior human resources to be achieved.
\end{abstract}

Keywords: Human Resources, Marketing unit. Career Development Model

\section{Introduction}

Career growth is mainly necessary for both private and state-owned companies. This is because career growth is focused on solving future business challenges facing competitors. Career growth has a future existence that depends on human resources, because it must carry out career growth for employees, which is implemented systematically and sustainably every year. In fact, development of career is one of the activities in management of human resource applied as a formal activity that is carried out in an integrated manner with other activities with human resources [1], [2], [3].

Career growth is very important for private and public companies because of career growth is a guideline for employees in pursuing career growth. If a private company or government is not promoting a career, the company or government will not be able to advance its career. Career development is the range of positions or positions held by an individual during his tenure, both in private companies and in government [4], [5], [6], [7]. Career growth as activity is mainly objected at improving and increasing the efficiency of the job performed by employees so that they can increasingly make a better contribution to the achievement of the organization's business goals [8], [9], [10], [11].

Career growth is associated not only with organizational characteristics, but also with individual characteristics and work discipline. The people who plan and the organizations who 
lead. Employee career development is a formally structured approach or activity aimed at increasing the level of job satisfaction, knowledge, and ability of employees so that organizations can make sure the right qualifications and experience of people are in the organization [12], [13], [14], [15], [16].

In the world of work, the most important element is the creation of characteristics by employees, because the creation of characteristics is a spirit in which all programs are formed from life experience (employees) are the forerunners of everything. This program then forms a belief system that can ultimately shape a mindset that can influence his behaviour. When an embedded program conforms to the principles of universal truth, its behaviour conforms to the laws of nature. As a result, this behaviour brings peace and happiness. On the other hand, when a program does not conform to the principles of universal law, its behaviour is harmful and leads to suffering. Hence, serious attention must be paid to the mind. These employees' thoughts can be realized through career growth and work discipline. [17]. [18], [19], [20], [21], [22].

According to the Financial Services Authority - West Java Regional Office 2, in Bandung, along with the development of financial and banking institutions in West Java, the number of all financial institutions in West Java, especially in Bandung, has grown quite rapidly. reaching about 274 financial institutions, consisting of 100 banks. the public and private sector, as well as 174 other financial institutions such as pension funds, life insurance, etc. (OJK Kantor Regional 2 Jawa Barat: 2018). PT. Bank Negara Indonesia (Persero), or better known as Bank BNI, is the main body of the Indonesian banking industry. As the first state-owned bank founded in 1946, Bank BNI is one of the largest banks in Indonesia in terms of assets, loans, and thirdparty funds (DPK). Total assets reached Rs 763.52 trillion as of October 2018 [23]. For the West Java region itself, Bank BNI narrows down to Bandung Regional Branch, or WBN for short, which has a total of 145 branches, including main branches (KCU), subsidiary branches (KCP) and cash desks (KK).

Realizing how competitive the banking sector is in Bandung City, a model is needed that can enhance the advantages of the main branch of Bandung College (KCU PTB). Regarding the importance of implementing an employee career model, it is necessary to apply it to PT. Bank Negara Indonesia (Persero) Tbk, Especially at BNI Bandung College Branch to maintain customer satisfaction and loyalty. This is also necessary to maintain the effectiveness of the organization and to maintain the BNI's \# 1 Best State Bank award in Jakarta, Indonesia. The award was presented to BNI at the 2018 Satisfaction Loyalty Engagement Awards. As a result of customer satisfaction, loyalty and emotional attachment study carried out by Marketing Research Indonesia (MRI) and Infobank Magazine.

Based on initial observations, the authors concluded that the career development model for employees in the marketing department of Bank BNI, Bandung College Branch was considered not optimal. This can be judged by the phenomena that occur at the branch of BNI Bandung College, including a) there is no Standard Operating Procedure (SOP) for career development in the Marketing Department of BNI Bank, Bandung College Branch. This makes career planning for employees and organizations difficult; b) there are no standards or requirements for general education in the promotion process in the Marketing Department of Bank BNI, Bandung College Branch.

This affects the low competitiveness and motivation of employees when pursuing career growth; c) opportunity to participate in training on leadership, sales and effective communication is not realized in the marketing department; d) there is no openness and mechanism for the introduction of mutations in the marketing department; e) there are no job requirements to be met by the Marketing Department; f) the Marketing Department still has many long-term employees with no career opportunities. 
According to these problems, this study formulates a model of career development for marketing unit.

\section{Implementation of Career Development in Marketing Section of PT. Bank Negara Indonesia (Persero) Tbk., Branch office of Bandung College}

Before formulating a model, the study explores the application of career development in the Marketing Section, namely:

a. Training.

The company conducts periodical training, as well as training according to needs that is carried out fairly andequitably for all levels. This is evidenced by the training carried out for the marketing department, namely: 1) the retail banking training program aims to provide participants with a good understanding of the work program at the branch that has been improved, ways to do marketing proactively by Branch Officesas well as the principles and workings of the Share Processing Unit (SPU) will be able to carry out theirduties professionally both in service and in marketing, while the material is branch process reengineering, product marketing and enhancement, and share processing unit; 2) Branch Marketing Assistant Training Program. The purpose of the training is so that participants have the knowledge and skills to carry out their duties well; 3) Sub-Branch Marketing Assistant Training Program aims to participants can handle the work properlyand correctly in the marketing of products / services of Bank PT. Bank Negara Indonesia (Persero) Tbkin general and credit in particular

b. Evaluation

Performance appraisal focuses on assessment as an assessment measurement process. The main thing about this assessment is that techniques (such as scale patterns) can be developed to increase the accuracy and validity of the assessment. This research is unique because the models presented do not facilitate the integration of science and its application in performance appraisal. This is because they do not identify the variables that are very important in the assessment, and they fail to achieve the objectives so that other researchapproaches and practices are needed. Implementation of the assessment process at the marketing department of the BNI Bandung branch office iscarried out periodically, transparently, and objectively and communicated with employees, because this is very directly related to wage adjustments, placement and development plans, and termination of employee employment relationships.

c. Mutation

The consideration of the implementation of the transfer is by considering the work performance, skills, discipline, conduct and expertise/ability of the employee, the period of service, the period and the needs andinterests of the company which are carried out objectively and there are no deviations from the existing system, while still considering the welfare and facilities. for employees if it is due to the company's wishes.

d. Promotion

Carrying out promotions in the field of marketing PT. Bank Negara Indonesia (Persero) Tbk., Is carried out in the hope of improving employee performance based on an annual assessment and is based on the following points: 1) Trust, as promotion must be based on trust or trust in honesty, the skills and skills of the respective employee for the proper fulfilment of their duties in positions. New employees are promoted if the employee demonstrates integrity, skills, and ability in the performance of the position; 2) Fairness, as promotions should be based on fairness to assess the honesty, skills and abilities of all employees, and the assessment should 
be objective and not in favour of preferences, likes or dislikes, so the best rated employees should have the first opportunity. will be promoted regardless of the position held. Ethnicity, class, and pedigree. Equitable career advancement will be a motivation tool for employees to improve their performance; 3) Creation, because the promotion should be based on existing listings, because the promotion is only possible with a vacant position, that is, job descriptions should be available, and the promotion should be adapted to existing information about vacancies in the company.

\section{Career Development Model in Marketing Unit of PT. Bank Negara Indonesia (Persero) Tbk., Branch office of Bandung College}

Developing career development programs helps managers make creative career decisions for employees. For this reason, when developing a career development program, it is necessary to distinguish three phases [24], which consist of the following:

a. Planning phase

This phase is an activity to harmonize the design of the employees and the organizational structure in relation to career development in their environment. The purpose of this phase is to identify the strengths and weaknesses of the employees in the performance of their duties so that various efforts can be made to help the employees, including: 1) help in choosing a career path with available resources; 2) Correcting the shortcomings or weaknesses of employees who show sincerity and need it for a successful career.

b. Leadership phase

This phase aims to help employees make their plans come true by identifying the type of career they want, and the steps required to achieve them. Two approaches can be used, namely: 1) guidance through career guidance; 2) differences in the provision of information services, which include the following activities: a) an open target system for reporting job vacancies; b) this briefing takes place through the provision of information for all employees, in particular with regard to career development; c) providing information on the inventory of workers' skills that every worker can and can know; d) information on career development in the form of diagrams showing the possible directions and opportunities in the organization; and e) organize a career development resource centre, which is a collection of work-related materials and others.

c. Development phase

This stage represents the grace period that the employee will need to meet the requirements that will allow them to move from one position to another that they want. Activities that can be carried out, including a) organizing a mentoring system; b) training; c) work rotation; and d) Scholarship Program

Below is a diagram of Career Development Model as a model purposed for PT Bank Negara Indonesia (Persero) Tbk, a branch of Bandung College:

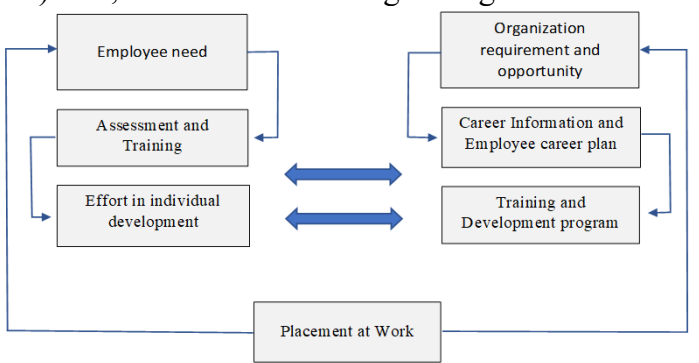

Fig 1. Career Development Model in PT. Bank Negara Indonesia (Persero) Tbk, Branch Office of Bandung College 


\section{Conclusion}

According to the discussion about development of career of marketing employees at BNI Bandung College Branchoffice, then refer to the research conducted, it is highlighted that development of career employee, both in terms of career management and career planning at BNI Bandung College Branch, is still not optimal, although there are certain parts that have been implemented and become part of the employee career development process. In carrying out career development BNI implements the Individual Development Plan (IDP) which includes career planning and employee competency development. This is intended to provide equal opportunities to all employees.

The inputs obtained from IDP are then put into a Learning Need Analysis (LNA) which is the basis for guidance for unit leaders in developing the competencies of employees under their responsibility. BNI also implements Dual Career Path Management (Dual CPM) which gives employees the opportunity to choose a managerial or specialist career path. This program is a continuous program and is carried out in stages. Related obstacles faced by marketing employees at BNI Bandung College Branch, this study highlighted about changes in marketing KPIs by Head Office in the current year; there are assignments and responsibilities outside of KPIs that are not inline to performance; and lack of communication and support from related units in administrative matters that have an impact on career development.

Overall, the career development model implemented by BNI, especially at the BNI Branch Office of Bandung College is clear and measurable, but unfortunately in its implementation there are still many obstacles that must be faced and must be resolved, especially in the realm of implementation. A model that does not work well will result in the performance of individuals and companies experiencing a decline, this is what happened to the BNI Bandung College Branch. The career development model that is carried out is divided into 3 phases, namely the planning phase, the direction phase, and the development phase. Even though there is a clear model, if it is not driven by high motivation, the model will be hampered and will affect the achievement of organizational goals.

As recommendation, to overcome the problem, especially the priority problem, which is related to the non-optimal career development of employees, the model formulated as problem solving is a career development model should be applied by PT Bank Negara Indonesia (Persero) Tbk, Branch Office of Bandung College.

\section{References}

[1] Alwi, Syafarudin. 2008. Manajemen Sumber Daya Manusia. Edisi kedua. Yogyakarta: BPFE Yogyakarta

[2] Ambar. 2009. Manajemen Sumber Daya Manusia. Yogyakarta: Graha Ilmu.

[3] Flippo, Edwin B. 2002. Personel Management (Manajemen Personalia), Edisi VII Jilid II.TerjemahanAlponso S. Jakarta: Erlangga.

[4] Fuad, Noor dan Ahmad, Gofur. 2009. Integrated Human Resources Development. Jakarta: PT Grasindo.

[5] Gomes, Faustino Cardoso. 2013. Human Resource Management: Terjemahan Andi Offset. Yogyakarta.

[6] Hariandja, Marihot Tua Effendi. 2010. Manajemen Sumber Daya Manusia, Edisi Revisi, Cetakan Kedua. Jakarta: PT. Grasindo.

[7] Bernardin, John, H \& Russel, Joyce E. A. 2013. Human Resource Management, an Experiental Approach, Mc Graw- Hill International Edition. Sixth Edition. Singapure.

[8] Danang, Sunyoto. 2012. Manajemen Sumber Daya Manusia. Jakarta: PT Buku Seru. Davis, Gordon B. 2004. Sistem Informasi Manajemen. Jakarta: Gramedia 
[9] Mangkunegara, A.A Anwar Prabu. 2012. Manajemen Sumber Daya Manusia.Bandung: PT. Remaja Rosdakarya.

[10] Manulang. 1984. Manajemen Personalia. Jakarta: Ghalia Indonesia.

[11] Mathis, R.L. \& J.H. Jackson. 2006. Human Resource Management: Manajemen Sumber Daya Manusia. Terjemahan Dian Angelia. Jakarta: Salemba Empat.

[12] Milkovich, George T., and John W. Boudreau. 1997. Human Resource Management. 8th Edition. McGrawhill.

[13] Harsono. 2011. Sistem Administrasi Kepegawaian. Bandung: FOKUSMEDIA

[14] Hasibuan, Malayu S.P. 2012. Manajemen Sumber Daya Manusia, Edisi Revisi.Jakarta: PT. Bumi Aksara.

[15] Heene, A. \& Desmidt, S. 2010. Manajemen Model Keorganisasian Publik. PT Refika Aditama.

[16] Hutapea, Parulian dan Nurianna Thoha. 2008. Kompetensi Plus: Teori, Desain, Kasus dan Penerapan untuk HR dan Organisasi yang Dinamis. Jakarta. Penerbit : Gramedia Pustaka Utama.

[17] Nitisemito, Alex, S .2005. Manajemen Personalia (Manajemen Sumber Daya Manusia, Edisi Kelima, Cetakan Keempat belas. Jakarta: Ghalia Indonesia.

[18] Notoatmodjo, Soekidjo. 2009. Pengembangan Sumber Daya Manusia. Cetakan Keempat. Edisi Revisi. Jakarta: Rineka Cipta.

[19] Panggabean, S., Mutiara. 2004. Manajemen Sumber Daya Manusia. Bogor: Ghalia Indonesia.

[20] Rachmawati, Ike Kusdyah. 2008. Manajemen Sumber Daya Manusia. Yogyakarta:CV Andi Offset.

[21] Sadili Samsudin. 2006. Manajemen Sumber Daya Manusia. Bandung: CV. PUSTAKA SETIA.

[22] Spencer, Lyle \& Signe M. Spencer. 1993. Competence at Work, Models For Superior Performance. Canada: John Wiley \& Sons, Inc.

[23] BNI Financial Report (2018)

[24] Nurmasari.: Peranan Penting Perencanaan dan Pengembangan Karier. Jurnal PUBLIKa, Vol.1, No.2, Oktober, page 268-281 (2015). 